\author{
Associate Professor Eugenia GRECU, PhD \\ E-mail: eugenia.grecu@upt.ro \\ Department of Management \\ Politehnica University of Timisoara \\ Professor Claudiu Tiberiu ALBULESCU, PhD \\ E-mail: claudiu.albulescu@upt.ro \\ Department of Management \\ Politehnica University of Timisoara \\ Professor Ion Profir PÂRŢACHI, PhD \\ E-mail:ipartachi@ase.md \\ Department of Econometrics and Economic Statistics \\ Academy of Economic Studies of Moldova, Republic of Moldova \\ Professor Stelian STANCU, PhD \\ E-mail:stelian_stancu@yahoo.com \\ Department of Economic Informatics and Cybernetics \\ The Bucharest University of Economic Studies \\ Associate Professor Daniela Livia TRAȘCĂ, PhD \\ E-mail:daniela.trasca@ase.ro \\ Department of Economy and Economic Policies \\ The Bucharest University of Economic Studies

\section{OUTPUT, UNCERTAINTY AND FUEL PRICES IN THE EU COUNTRIES}

Abstract. In this paper we test whether the Friedman's second hypothesis is verified in the case of European Union countries, and we check for the role of fuel prices in influencing the economic output. More precisely, relying on both General Method of Moments and Mean Group approaches for a panel of EU-28 countries, over the period 2005 to 2017, we analyze the impact of inflation uncertainty, growth uncertainty and fuel prices on the economic growth rate. We show that inflation and growth uncertainty, as well as fuel prices, have a positive impact on economic growth in the short run; In the long run, the results reveal that inflation uncertainty has a negative influence on economic output, whereas the effect of economic growth uncertainty and fuel prices is no longer significant. We show that the diesel prices have a stronger impact on economic growth in the short run, compared with gasoline prices.

Keywords: output, inflation, output, uncertainty, fuel prices, EU countries.

JEL Classification: E23, E31, C23, 047

DOI: $10.24818 / 18423264 / 54.1 .20 .02$ 
Eugenia Grecu, ClaudiuTiberiuAlbulescu, Ion Profir Pârțachi, StelianStancu, Daniela Trașcă

\section{Introduction}

The shift from the short-run Phillips curve describing the inflationunemployment trade-off during the 1970s, was explained by the lack of commitment toward inflation expectations that causes a high inflation uncertainty (Friedman, 1968). According to Friedman (1977), inflationary pressures lead to more inflation volatility and uncertainty. This assumption is known as the first hypothesis of the Friedman's (1977) Nobel lecture, which was further discussed and empirically tested by Ball (1992) (Friedman-Ball hypothesis), while Cukierman and Meltzer (1986) formulated an alternative hypothesis, showing that inflation uncertainty generates inflation (Cukierman-Meltzer hypothesis). The second hypothesis of the Friedman's (1977) Nobel lecture states that a higher inflation uncertainty reduces economic efficiency generating confusing price signals in the market. Consequently, according to this assumption, inflation uncertainty negatively impacts the economic growth. The purpose of our paper is to test this second hypothesis in the case of European Union (EU) countries. In the period following the recent Global crisis, the economic recovery in the EU is still missing. We posit that both inflation uncertainty and energy prices (we use fuel prices as a proxy) explain the lack of growth return in this region.

Recent empirical studies investigating the interaction between inflation uncertainty and economic output show mixed findings that require additional investigations (Ekrem and Sankar, 2019). While most of these studies document a negative impact of inflation uncertainty on the output (e.g. Albulescu et al., 2019), other papers (e.g. Pintilescu et al., 2014) report inconclusive results. These mixed findings might be influenced not only by the particularities of analyzed economies, and by the empirical methods used to compute the inflation uncertainty and to test its effect on the economic growth, but also by the economic context, which is largely influenced by the trend of energy and oil prices. Oil prices might have either a direct effect on economic growth influencing consumption and investment, or an indirect effect, influencing the production cost, the general prices, but also the inflation uncertainty. ${ }^{1}$ As far as we know, Bhar and Mallik (2013) are the only scholars who consider the role of international oil prices in this equation. However, they check the impact of international oil price shocks and use dummy variables to see how jumps in oil prices impact the inflation and economic activity. They practically test the predictive effect of oil prices on the economic output, in line with Narayan et al. (2014).

Different from Bhar and Mallik (2013), we focus on the role of fuel prices, considering the price level and not the shock prices. Recent studies re-investigated the link between oil and growth focusing on non-linearities (e.g. van Eyden et al., 2019), and most of them show that international oil prices negatively impact the

\footnotetext{
${ }^{1}$ Noteworthy recent paper show that the technological change influencing the economic output is biased toward energy (Karanfil and Yeddir-Tamsamani, 2010; Zha et al., 2018).
}

DOI: $10.24818 / 18423264 / 54.1 .20 .02$ 
economic growth, in particular in oil-importing countries. However, for the real economy it is realistic to consider fuel prices, which represents more than $90 \%$ of the energy used in the transport sector (Mo et al., 2019). In fact, fuel prices are largely influenced not only by international oil prices, but also by the profit margins established by oil companies and by the tax level imposed by each government. Consequently, shocks in international oil prices might be counterbalanced by the policies related to fuel prices. Therefore, in the long run, the level of fuel prices is important for the economic output. At the same time, a higher volatility of fuel prices influences both the output and inflation uncertainty through inflation expectations. Therefore, we also test for the effect of fuel prices increases over the previous period and we construct an interaction dummy variable with the level of fuel prices (where the dummy variable takes value 1 if the fuel prices increase and 0 otherwise). ${ }^{2}$ In addition, we expect that diesel prices should have a stronger effect on economic growth compared with gasoline prices, given the importance of diesel in industrial transports.

The second contribution of our paper is related to the empirical methodology we use to test the link between output, uncertainty and fuel prices. The mixed findings reported in the previous papers could be biased by the endogeneity effect between economic growth and uncertainty on the one hand, and economic growth and fuel prices on the other hand. To overcome this issue, we resort to a classic General Method of Moments (GMM) specification, comparing a difference-GMM model (Arellano and Bond, 1991) and a system-GMM specification (Blundell and Bond, 1998). Further, we posit that the impact of fuel prices on the economic activity is not only influenced by the status of a country (i.e. net oil-importing or oil-exporting country), but also by the time horizon we consider. Given the endogeneity issue, the short-run relationship between output and fuel prices might be positive, given that both variables are influenced by an increased consumption. Further, considering the role of fuels is important in the case of EU countries, where economic business cycle is highly correlated with the United States (US) business cycle. The short-run positive impact of oil prices on the US economy is well documented. Nevertheless, in the long run, the effect of fuel prices on the output might became negative, given that cost accumulation and investment cycle depress economic activity. To address this issue, and to check for the robustness of our findings, we also resort to a Mean Group (MG) estimation (Pesaran and Smith, 1995).

Third, compared with most recent studies, we use a different approach to compute the inflation and growth uncertainty. Given that inflation uncertainty is an unobserved phenomenon, recent works resort to complex techniques to measure the uncertainty level, relying on unobserved components models (Chan, 2017). However, these methods are prone to criticism because their results do not

${ }^{2}$ The impact of the changes in oil prices on inflation was recently investigated by LópezVillavicencio and Pourroy (2019).

DOI: 10.24818/18423264/54.1.20.02 
Eugenia Grecu, ClaudiuTiberiuAlbulescu, Ion Profir Pârțachi, StelianStancu, Daniela Trașcă

necessarily reflect the market expectations. Thus, we compute the inflation (output) uncertainty as being the difference between the recorded and the forecasted level of inflation (output).

Finally, we consider the case of EU-28 countries which is particularly appealing. The level of fuel prices recorded in the EU is very high, with noteworthy effects on the economic activity and generating social cost (e.g. the yellow vest movement in France). At the same time, different from the US, the EU economic recovery after the recent global crisis is rather modest and the uncertainties' manifestation might explain this delay.

The rest of the paper presents a brief literature review (section 2), data and methodology (section 3), the main results (section 4) and the robustness check (section 5). The last section concludes and underlines the policy implications of our findings.

\section{The Friedman's (1977) second hypothesis: literature review}

Whereas the link between inflation and its uncertainty is intensively tested with opposite findings by the early literature (e.g. Ungar and Zilberfarb, 1993), and by noteworthy recent papers (Albulescu et al., 2019), much less attention is paid to the impact of inflation uncertainty on economic output. The few recent studies in this area underline, in general, a negative impact of inflation uncertainty on the economic output, but several works find no significant relationship or, on contrary, report a positive influence of uncertainty on the economic output.For example, using a time-frequency approach and historical data, Albulescu et al. (2019) show that inflation uncertainty depressed the United States (US) economic growth. Resorting to a bivariate constant conditional correlation generalized autoregressive conditional heteroskedastic (AR(p)-cccGARCH(1,1)) specification to model inflation and output uncertainties, Jiranyakul and Opiela (2011) find that increased inflation uncertainty decreases output in Thailand. Similar findings are reported by Mohd et al. (2013) for a set of ASEAN countries. However, using a VARFIMABEKK MGARCH model for the United Kingdom (UK) and covering the 1957:Q2-2006:Q4 period, Özdemir (2010) documents on contrary, a strong positive effect of inflation uncertainty on inflation and output growth. At the same time, Pintilescu et al. (2014) report inconclusive findings about the impact of inflation uncertainty on the output in the case of Eastern European Economies.

A recent strand of the literature does not directly focus on the Friedman's (1977) second hypothesis but investigate the relationship between economic policy uncertainty (EPU) and economic output. In the construction of EPU indexes researchers usually resort to forecasts errors. Therefore, the metrics we propose to assess the inflation and output uncertainties are linked with the induced-policy uncertainty. 
Output, Uncertainty and Fuel Prices in the EU Countries

\section{Data and methodology}

\subsection{Data}

We use data for EU-28 countries for the period from 2005 to 2017. Fuel prices are available in the Weekly Oil Bulletin of the European Commission starting with 2005 (for this analysis we compute the average annual data of fuel prices (EUR/l) available on a weekly basis). Output and inflation annual statistics are extracted from Eurostat database. To compute the uncertainties series, we use one-year output and inflation forecasts from European Economic Forecast (Spring editions). Therefore, the uncertainty is calculated as follows:

uncertainty $=\mid$ recorded level $_{\mathrm{t}}$ - forecasted level $\mathrm{t}_{\mathrm{t}-1} \mid$.

Our dependent variable is therefore the output (y). The explanatory variables are the inflation uncertainty (iu), the output uncertainty (yu), the inflation rate (i), and the fuel prices. In the case of fuel prices, we consider alternatively the effect of gasoline prices (fuel1) and diesel prices (fuel2). Given the diesel prices importance in production and transportation costs, we expect a higher influence on the economic output compared with the gasoline prices. Further, we perform the estimations for the entire EU-28 sample, as well as for a second sample, excluding Bulgaria, Croatia and Romania that have joined the EU after 2005 (the starting date of our analysis), to check the robustness of our findings.

Before the empirical analysis we first apply a series of panel unit root tests to check the stationarity of our series (Table 1). We notice that the panel unit root tests indicate the absence of unit roots for the output, inflation and their uncertainties, while for the fuel prices the findings are mixed.

Table 1. Panel unit root tests

\begin{tabular}{lllll}
\hline $\begin{array}{l}\text { cross- } \\
\text { sections }\end{array}$ & $\begin{array}{l}\text { Levin, Lin \& Chu } \\
\mathrm{t}^{*}\end{array}$ & $\begin{array}{c}\text { Im, Pesaran } \\
\text { and Shin } \\
\text { Z-t-tilde-bar }\end{array}$ & $\begin{array}{c}\text { ADF - Fisher } \\
\text { Inverse Chi- } \\
\text { square P }\end{array}$ & $\begin{array}{l}\text { ADF - Fisher } \\
\text { Inverse Normal Z }\end{array}$ \\
\hline $\mathrm{y}$ & $-9.568^{* * *}$ & $-4.683^{* * *}$ & $119.726 * * *$ & $-5.676^{* * *}$ \\
$\mathrm{iu}$ & $-6.110^{* * *}$ & $-4.701 * * *$ & $122.980 * * *$ & $-5.7525 * * *$ \\
yu & $-13.093 * * *$ & $-5.478^{* * *}$ & $146.285 * * *$ & $-7.125 * * *$ \\
$\mathrm{i}$ & $-5.399 * * *$ & $-3.610^{* * *}$ & $92.60 * * *$ & $-3.904 * * *$ \\
fuel1 & & -2.032 & 51.407 & -1.221 \\
fuel2 & & $-2.988^{*}$ & 66.806 & $-2.588^{* * *}$ \\
\hline
\end{tabular}

Notes: (i) the null hypothesis for all the tests is the presence of unit roots (the $t^{*}$ test assumes common unit root process while the other tests assume individual unit root process); (ii) *, **, ***, mean stationarity (in level) significant at 10 $\%, 5 \%$ and $1 \%$; (iii) $y$-output growth, iu-inflation uncertainty, yu-output uncertainty, $i$-inflation rate, fuell - gasoline retail prices including taxes, fuel 2 - diesel retail prices including taxes; (iv) the LLC test cannot be applied for fuel series as it requires strongly balanced data (data are not available for Bulgaria and Romania before 2007 - their accession to the EU membership).

DOI: 10.24818/18423264/54.1.20.02 
Eugenia Grecu, ClaudiuTiberiuAlbulescu, Ion Profir Pârțachi, StelianStancu, Daniela Trașcă

\subsection{The GMM approach}

To overcome the bias generated by the endogeneity that characterize the relationship between output on the one hand, and uncertainty, fuel prices and inflation on the other hand, we first use a dynamic-GMM approach:

$\Delta \mathrm{Y}_{\mathrm{i}, \mathrm{t}}=\beta_{1} \Delta \mathrm{Y}_{\mathrm{i}, \mathrm{t}-\mathrm{s}}+\beta_{2} \Delta \mathrm{X}_{\mathrm{i}, \mathrm{t}}+\Delta \mu_{\mathrm{i}}+\Delta \varepsilon_{\mathrm{i}, \mathrm{t}}$

where $Y_{i, t}$ is the output, $X_{i, t}$ is the vector of explanatory variables (inflation uncertainty, output uncertainty, inflation and fuel prices), $\mu_{i}$ are between-entity errors, $\varepsilon_{\mathrm{i}, \mathrm{t}}$ are within-entity errors.

Arellano and Bond (1991) propose a difference-GMM estimator where lagged values of variables are used as instruments and which supposes the absence of second-order autocorrelation:

$\mathrm{E}\left[\mathrm{Y}_{\mathrm{i}, \mathrm{t}-\mathrm{s}}\left(\varepsilon_{\mathrm{i}, \mathrm{t}} \varepsilon_{\mathrm{i}, \mathrm{t}-\mathrm{t}}\right)\right]=0$, and

$\mathrm{E}\left[\mathrm{X}_{\mathrm{i}, \mathrm{t}-\mathrm{s}}\left(\varepsilon_{\mathrm{i}, \mathrm{t}}-\varepsilon_{\mathrm{i}, \mathrm{t}-1}\right)\right]=0$, for $\mathrm{s} \geq 2$ and $\mathrm{t}=3, \ldots, \mathrm{T}$.

Given that the lagged values of explanatory variables are considered weak instruments, Blundell and Bond (1998) propose a system-GMM estimator, with two equations, one in level and the second in first difference. In this case, the lagged values (in levels) are used as instruments and the additional moment conditions are:

$E\left[\left(Y_{i, t-1}-Y_{i, t-2}\right)\left(\mu_{i}+\varepsilon_{i, t}\right)\right]=0$,

$\mathrm{E}\left[\left(\mathrm{X}_{\mathrm{i}, \mathrm{t}-\mathrm{-}}-\mathrm{X}_{\mathrm{i}, \mathrm{t}-2}\right)\left(\mu_{\mathrm{i}}+\varepsilon_{\mathrm{i}, \mathrm{t}}\right)\right]=0$, for $\mathrm{s} \geq 2$ and $\mathrm{t}=3, \ldots, \mathrm{T}$.

This approach, however, might be affected from an over proliferation of instruments. Therefore, for robustness purpose we compare the results of both dynamic-GMM estimations.

\subsection{The MG approach}

The MG estimator advanced by Pesaran and Smith (1995) and Pesaran et al. (1997) has the advantage to consider the endogeneity issues, and to provide a shortand a long-run perspective on the estimated relationship. It is consistent with both $\mathrm{I}(1)$ and $\mathrm{I}(0)$ series, relying on the maximum likelihood estimation. The MG designed for heterogeneous panels allows the intercepts, slope coefficients and error variances to vary across groups. It represents an Autoregressive Distributed

DOI: $10.24818 / 18423264 / 54.1 .20 .02$ 
Output, Uncertainty and Fuel Prices in the EU Countries

Lag (ARDL) cointegration technique. Consequently, the dynamic panel specification is:

$\mathrm{Y}_{\mathrm{i}, \mathrm{t}}=\sum_{\mathrm{j}=1}^{\mathrm{p}} \lambda_{\mathrm{i}, \mathrm{j}} \mathrm{Y}_{\mathrm{i}, \mathrm{t}-\mathrm{j}}+\sum_{\mathrm{j}=0}^{\mathrm{q}} \delta_{\mathrm{i}, \mathrm{j}}^{\prime} \mathrm{X}_{\mathrm{i}, \mathrm{t}-\mathrm{j}}+\mu_{\mathrm{i}}+\varepsilon_{\mathrm{i}, \mathrm{t}}$

where $i$ is the number of countries and $t$ is the number of years, $Y_{i, t}$ is the output, $\mathrm{X}_{\mathrm{i}, \mathrm{t}}$ is the $\mathrm{k} \times 1$ vector of explanatory variables, $\delta_{\mathrm{i}, \mathrm{j}}^{\prime}$ are coefficients, $\lambda_{\mathrm{i}, \mathrm{j}}$ are scalars, $\mu_{\mathrm{i}}$ are group effects, $\varepsilon_{\mathrm{i}, \mathrm{t}}$ are the estimation errors.

Eq. (7) can be reparametrized into an error correction equation:

$\Delta \mathrm{Y}_{\mathrm{i}, \mathrm{t}}=\emptyset_{\mathrm{i}}\left(\mathrm{Y}_{\mathrm{i}, \mathrm{t}-\mathrm{j}}-\theta_{\mathrm{i}}^{\prime} \mathrm{X}_{\mathrm{i}, \mathrm{t}}\right)+\sum_{\mathrm{j}=1}^{\mathrm{p}-1} \lambda_{\mathrm{i}, \mathrm{j}}^{*} \Delta \mathrm{Y}_{\mathrm{i}, \mathrm{t}-\mathrm{j}}+\sum_{\mathrm{j}=0}^{\mathrm{q}-1} \delta_{\mathrm{i}, \mathrm{j}}^{*} \Delta \mathrm{X}_{\mathrm{i}, \mathrm{t}-\mathrm{j}}+\mu_{\mathrm{i}}+\varepsilon_{\mathrm{i}, \mathrm{t}}$,

where $\emptyset_{\mathrm{i}}$ is the error-correction adjustment term, $\theta_{\mathrm{i}}$ is the vector that explains the long-run relationships between variables.

\section{Main empirical findings}

\subsection{The GMM results}

Three models are tested for each specification (i.e. difference - and systemGMM). In the first model (Model 1) we consider the role of inflation uncertainty, growth uncertainty and fuel prices in explaining the economic output dynamics. In Model 2 we include in addition an interaction dummy between the fuel prices and a dummy variable which takes value 1 if the fuel prices increase over the previous period (year). We thus resort to a difference-in-difference estimation. Finally, in Model 3 we also consider the inflation level in explaining the output.

We first discuss the GMM results for the EU-28 countries when the gasoline retail prices are included in the estimations (Table 2).

Table 2. GMM results (gasoline prices)

\begin{tabular}{|c|c|c|c|c|c|c|}
\hline \multirow{2}{*}{$\begin{array}{l}28 \text { cross- } \\
\text { sections }\end{array}$} & \multicolumn{3}{|c|}{ difference-GMM } & \multicolumn{3}{|c|}{ system-GMM } \\
\hline & Model 1 & Model 2 & Model 3 & Model 1 & Model 2 & Model 3 \\
\hline $\operatorname{lag}(1)$ & $0.453 * * *$ & $0.460 * * *$ & $0.446 * * *$ & $0.475^{* * * *}$ & $0.486 * * *$ & $0.448 * * *$ \\
\hline iu & $0.274 * * *$ & $0.187 *$ & 0.065 & $0.259 * * *$ & 0.125 & -0.133 \\
\hline yu & $1.214 * * *$ & $1.209 * * *$ & $1.207 * * *$ & $1.298 * * *$ & $1.293 * * *$ & $1.308 * * *$ \\
\hline fuel1 & $9.287 * * *$ & $8.552 * * *$ & $8.271 * * *$ & $9.850 * * *$ & $8.963 * * *$ & $8.394 * * *$ \\
\hline dum_f1 $1 \times$ fuel1 & & 0.776 & $0.835^{*}$ & & $0.937 * *$ & $0.855^{* *}$ \\
\hline $\mathrm{i}$ & & & 0.091 & & & $0.275^{* *}$ \\
\hline $\mathrm{c}$ & 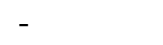 & - & 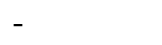 & - & - & \\
\hline & $4.223 * * *$ & $4.030 * * *$ & $4.033 * * *$ & $4.564 * * *$ & $4.332 * * *$ & $4.442 * * *$ \\
\hline obse & 297 & 297 & 297 & 325 & 325 & 325 \\
\hline instruments & 136 & 137 & 197 & 158 & 159 & 230 \\
\hline
\end{tabular}

Notes: (i) lag( 1 ) is the first lag of the dependent variable; (ii) dummy variables are considered strictly exogenous; (iii) *,**, *** means significance at $10 \%, 5 \%$ and $1 \%$; (iv) $i$-inflation rate, iu - inflation uncertainty, yu-output uncertainty, fuell - gasoline retail prices; dum_fl $\times$ fuell - interaction dummy between fuell and dum_fl (which takes value 1 if the gasoline price increases in tcompared to $t-1$ and 0 otherwise), $c$-intercept.

DOI: 10.24818/18423264/54.1.20.02 
Eugenia Grecu, ClaudiuTiberiuAlbulescu, Ion Profir Pârțachi, StelianStancu, Daniela Trașcă

We notice a large consensus between difference- and system-GMM specifications. However, in the case of the EU economies we obtain a result that does not concur with Friedman's (1977) second hypothesis. More precisely, our findings show that inflation uncertainty has a positive but moderate impact on economic growth. These results also contrast those reported byBhar and Mallik (2013) for the UK and can be explained by the fact that a higher inflation uncertainty is recorded in periods with high inflation (in agreement with Friedman's (1977) first hypothesis), which are also characterized by stronger economic growth. In fact, when the inflation is introduced into equation (Model 3), the effect of inflation uncertainty disappears. These findings can be explained by the fact that, in the EU countries, the level of inflation is quite reduced, and the deflation represented the major threat for the economy, after the recent global crisis. Otherwise said, the expansionary monetary policies conducted by the EU member states have stimulated a small increase in price level and generated higher uncertainty, with moderate effects on economic growth. We also discover that the output growth uncertainty is a positive determinant of the growth rate in the EU countries, this time, in agreement with the findings reported by Bhar and Mallik (2013). This positive effect is more important compared to that of inflation uncertainty and confirms the Black's (1987) hypothesis.

The impact of fuel prices on the economic growth is positive, which might be surprising in the case of EU economies, which are net oil-importing countries. However, this result can be explained by the fact that an increased consumption leads to increased fuel prices and stimulate economic growth in the short run. In fact, our interaction dummy is positive, showing that increases in fuel prices are benefic for economic growth.

The results remain practically unchanged if the diesel prices are introduced into equation (Table 3). Nevertheless, contrary to our expectations, the coefficients' level in the case of diesel prices (fuel2) are sensible smaller compared to those of gasoline (fule1). It seems that the consumption and not the production cost elements has a larger impact on economic growth.

Although these findings look quite robust, they are in contradiction with most of previous findings reported in the empirical literature. In addition, the impact of inflation and fuels prices on the output is different in the short compared with the long run. Furthermore, our panel unit root tests show mixed findings regarding the stationarity of fuel price series, which can bias the empirical estimations. Therefore, in the next section we perform a MG analysis, which overcomes the above-mentioned limitations.

Table 3. GMM results (diesel prices)

\begin{tabular}{lllllll}
\hline $\begin{array}{l}28 \text { cross- } \\
\text { sections }\end{array}$ & \multicolumn{3}{c}{ difference-GMM } & \multicolumn{3}{c}{ system-GMM } \\
\hline & Model 1 & Model 2 & Model 3 & Model 1 & Model 2 & Model 3 \\
\cline { 2 - 7 } $\operatorname{lag}(1)$ & $0.435^{* * * *}$ & $0.443^{* * *}$ & $0.435^{* * *}$ & $0.457 * * *$ & $0.471 * * *$ & $0.438^{* * *}$ \\
iu & $0.221^{* * *}$ & 0.137 & 0.036 & $0.190^{* * *}$ & 0.054 & -0.160 \\
\hline
\end{tabular}


Output, Uncertainty and Fuel Prices in the EU Countries

\begin{tabular}{|c|c|c|c|c|c|c|}
\hline yu & $1.218 * * *$ & $1.214 * * *$ & $1.212 * * *$ & $1.307 * * *$ & $1.302 * * *$ & $1.310 * * *$ \\
\hline fuel2 & $7.800 * * *$ & $7.096 * * *$ & $6.902 * * *$ & $8.582 * * *$ & $7.694 * * *$ & $7.227 * * *$ \\
\hline dum_f $2 \times$ fuel 2 & & 0.730 & $0.824 *$ & & $0.926 * *$ & $0.872 * *$ \\
\hline $\mathrm{i}$ & & & 0.065 & & & $0.240 * *$ \\
\hline \multirow[t]{2}{*}{$\mathrm{c}$} & - & - & - & - & - & - \\
\hline & $3.656 * * *$ & $3.461 * * *$ & $3.418 * * *$ & $4.147 * * *$ & $3.905 * * *$ & $4.005 * * *$ \\
\hline observations & 297 & 297 & 297 & 325 & 325 & 325 \\
\hline instruments & 136 & 137 & 197 & 158 & 159 & 230 \\
\hline
\end{tabular}

Notes: (i) lag(1) is the first lag of the dependent variable; (ii) dummy variables are considered strictly exogenous; (iii) *,**, *** means significance at $10 \%, 5 \%$ and $1 \%$; (iv) $i$-inflation rate, iu-inflation uncertainty, yu-output uncertainty, fuel 2 - diesel retail prices; dum_f $2 \times f u e l 2$ - interaction dummy between fuel 2 and dum_f 2 (which takes value 1 if the diesel price increases in t compared to $t-1$ and 0 otherwise), $c$-intercept.

\subsection{The MG results}

Table 4 presents the results of the MG estimator when gasoline prices are considered.

Table 4. MG results (gasoline prices)

\begin{tabular}{|c|c|c|c|c|c|c|}
\hline \multirow{2}{*}{$\begin{array}{l}28 \\
\text { cross- } \\
\text { sectio } \\
\text { ns }\end{array}$} & \multicolumn{2}{|c|}{ Model 1} & \multicolumn{2}{|c|}{ Model 2} & \multicolumn{2}{|c|}{ Model 3} \\
\hline & $\begin{array}{c}\text { Long-run } \\
\text { coefficie } \\
t s\end{array}$ & $\begin{array}{l}\text { Short-run } \\
\text { coefficient }\end{array}$ & $\begin{array}{c}\text { Long-ruı } \\
\text { coeffici } \\
n t s\end{array}$ & $\begin{array}{c}\text { Short-rur } \\
\text { coefficie } \\
t s\end{array}$ & $\begin{array}{c}\text { Long-rur } \\
\text { coefficie } \\
t s\end{array}$ & $\begin{array}{l}\text { Short-run } \\
\text { coefficieni } \\
\text { s }\end{array}$ \\
\hline$\phi_{i}$ & & $-0.574 * * *$ & & $-0.54 \epsilon^{* * * *}$ & & -0.641 \\
\hline iu & $-3.689 * * *$ & $0.583 * * *$ & $\begin{array}{c}-{ }^{*} \\
5.05 \\
1\end{array}$ & $0.445 * *$ & $-2.29 * * *$ & 0.150 \\
\hline yu & 1.254 & -0.047 & $2.88 i$ & 0.025 & $0.67 i$ & 0.230 \\
\hline $\begin{array}{l}\text { fuel1 } \\
\text { dum_f1 } 1 \times f \\
\text { el1 }\end{array}$ & 1.548 & $10.45 * * *$ & $32.8:$ & $\begin{array}{l}9.502 * * * \\
0.396\end{array}$ & $6.60 t$ & $\begin{array}{l}2.717 \\
0.219\end{array}$ \\
\hline $\begin{array}{l}\mathrm{i} \\
\mathrm{c}\end{array}$ & & $-1.901 * *$ & & $-2.00 \subseteq$ & $1.832 *$ & $\begin{array}{c}0.635 \\
-0.361\end{array}$ \\
\hline \multicolumn{7}{|c|}{ 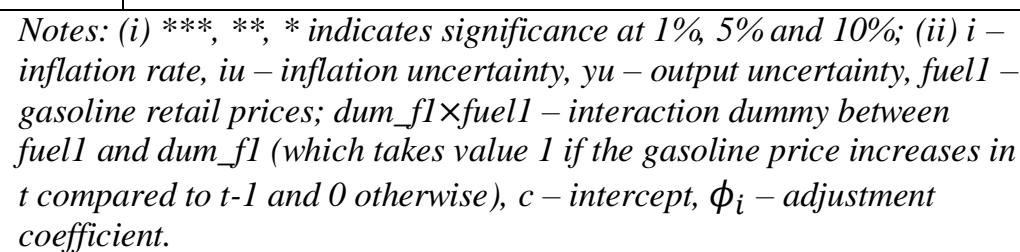 } \\
\hline
\end{tabular}

As in the case of the GMM approach, we test three models. These new results explain the mixed findings previously reported in the literature. First, when we disentangle between the short- and the long-run effect, we clearly notice that the inflation uncertainty has a positive impact on economic growth in the short run (in line with our GMM results and the findings reported by Özdemir, 2010). However, in the long run, our estimations show a negative influence of the

DOI: 10.24818/18423264/54.1.20.02 
Eugenia Grecu, ClaudiuTiberiuAlbulescu, Ion Profir Pârțachi, StelianStancu, Daniela Trașcă

inflation uncertainty on the economic output, confirming thus the Friedman's (1977) second hypothesis and the results reported by Albulescu et al. (2019), Jiranyakul and Opiela (2011) and by Mohd et al. (2013). Second, we notice that the effect of gasoline prices remains positive as in the GMM estimation and is significant only in the short run. Third, the impact of the output uncertainty is no longer significant. Forth, the interaction dummy's coefficient is not significant, showing that not the fuel price increases, but the price level influences the economic output. These findings are quite robust across the three models we test.

When we consider the impact of diesel prices, we obtain a more complex picture of the relationship between output, uncertainties and fuel prices (Table 5). Similar to the previous case when the effect of gasoline prices is tested, we notice that the inflation uncertainty has a significant positive impact on the output in the short run, and a negative influence in the long run, result explained by the strong connection between the inflation level and its uncertainty. However, different from the findings reported in Table 4, the impact of the output uncertainty on the economic growth is significant and positive in the long run, a result in agreement with that reported by Balaji et al. (2017) showing a positive relationship between output and its uncertainty. Also different from the findings reported in Table 4, we see that the diesel prices have both a short- and a long-run positive influence on the economic output (except for Model 3). Nevertheless, contrary to our expectation, the short-run impact of diesel prices on the output is slightly smaller compared to that of gasoline prices. In all the cases, the adjustment coefficient is negative and significant, showing evidence in the favor of the long-run relationship.

Table 5. MG results (diesel prices)

\begin{tabular}{|c|c|c|c|c|c|c|}
\hline \multirow{2}{*}{$\begin{array}{l}28 \text { cross- } \\
\text { sections }\end{array}$} & \multicolumn{2}{|c|}{ Model 1} & \multicolumn{2}{|c|}{ Model 2} & \multicolumn{2}{|c|}{ Model 3} \\
\hline & $\begin{array}{l}\text { Long-run } \\
\text { coefficient }\end{array}$ & $\begin{array}{l}\text { Short-run } \\
\text { coefficients }\end{array}$ & $\begin{array}{l}\text { Long-run } \\
\text { coefficient }\end{array}$ & $\begin{array}{l}\text { Short-run } \\
\text { coefficient: }\end{array}$ & $\begin{array}{l}\text { Long-run } \\
\text { coefficient: }\end{array}$ & $\begin{array}{l}\text { Short-run } \\
\text { coefficients }\end{array}$ \\
\hline$\phi_{i}$ & & $-0.59 ; * * *$ & & $-0.544 * * *$ & & $-0.424 * * *$ \\
\hline iu & $-1.988 * * *$ & $0.463 * * *$ & $-1.774 * *$ & 0.251 & $-5.89 \mathrm{C} *$ & -0.326 \\
\hline yu & $2.262 * * *$ & 0.007 & $2.744 * * *$ & 0.070 & 6.033 & 0.238 \\
\hline fuel2 & $10.875 * *$ & $9.580 * * *$ & $14.00 \leqslant *$ & $8.217 * * *$ & $63.44 \varepsilon$ & 3.321 \\
\hline$\underset{2}{\text { dum_f } 2 \times \text { fue }}$ & & & & 0.570 & & 0.273 \\
\hline $\mathrm{i}$ & & & & & -1.064 & $1.397 *$ \\
\hline c & & $-0.74 t$ & & -2.345 & & \\
\hline \multicolumn{7}{|c|}{$\begin{array}{l}\text { Notes: }(i) * * *, * *, * \text { indicates significance at } 1 \%, 5 \% \text { and } 10 \% ; i-\text { inflation rate, iu- } \\
\text { inflation uncertainty, yu - output uncertainty, fuel } 2-\text { diesel retail prices; } \\
\text { dum_fl } 1 \times \text { fuel } 1 \text { - interaction dummy between fuel } 2 \text { and dum_f2 (which takes value } 1 \text { if } \\
\text { the diesel price increases in t compared to } t-1 \text { and } 0 \text { otherwise), } c \text {-intercept, } \phi_{i}- \\
\text { adjustment coefficient. }\end{array}$} \\
\hline
\end{tabular}

To sum up, our GMM results supported by both difference- and systemGMM specifications are different from most of previous findings reported in the

DOI: $10.24818 / 18423264 / 54.1 .20 .02$ 
Output, Uncertainty and Fuel Prices in the EU Countries

literature and underline the positive impact of inflation uncertainty on the economic output. However, our second set of estimations explained the mixed empirical findings is relation with the second Friedman's hypothesis. The MG results state that the inflation uncertainty has a positive and significant influence in the short run, while in the long run the effect is negative. In addition, the fuel prices have a positive short-run impact on economic growth in the EU countries, while in the long run, the influence is more mitigated (this is also the case of the output uncertainty impact on economic growth). Therefore, we perform an additional set of robustness checks by which reveal excluding from our sample the two EU countries (Bulgaria and Romania) that have joined the EU in 2007, as well as Croatia (remember, our sample starts in 2005). ${ }^{3}$

\section{Additional robustness check analysis}

We discuss in this section the MG results the most complex findings. ${ }^{4}$ First, when the fuel prices are represented by the gasoline prices (fuel 1), like in the case of the main results, we notice a positive impact of inflation uncertainty on the output in the short run, while the long-run effect is negative. Similar to the results reported in Table 4, the influence of the output uncertainty is not significant, while the positive impact of fuel prices is recorded only in the short run. In addition, the price increases over the previous year have no significant impact on the economic growth at the EU level.

Table 6. MG robustness results (gasoline prices)

\begin{tabular}{|c|c|c|c|c|c|c|}
\hline \multirow{2}{*}{$\begin{array}{l}25 \text { cross- } \\
\text { sections }\end{array}$} & \multicolumn{2}{|c|}{ Model 1} & \multicolumn{2}{|c|}{ Model 2} & \multicolumn{2}{|c|}{ Model 3} \\
\hline & $\begin{array}{l}\text { Long-run } \\
\text { coefficients }\end{array}$ & $\begin{array}{l}\text { Short-run } \\
\text { coefficients }\end{array}$ & $\begin{array}{l}\text { Long-run } \\
\text { coefficient: }\end{array}$ & $\begin{array}{l}\text { Short-run } \\
\text { coefficients }\end{array}$ & $\begin{array}{l}\text { Long-run } \\
\text { coefficients }\end{array}$ & $\begin{array}{c}\text { Short-run } \\
\text { coefficien } \\
s\end{array}$ \\
\hline$\phi_{i}$ & & $-0.563 * * *$ & & $-0.521 * * *$ & & $-0.577 * *=$ \\
\hline iu & $-4.173 * * *$ & $0.652 * * *$ & $-5.846 * *$ & $0.497 * * *$ & $-2.581 * * *$ & 0.180 \\
\hline yu & 1.249 & -0.074 & 3.058 & -0.003 & 0.675 & 0.309 \\
\hline fuel1 & 0.940 & $11.26(* * *$ & $34.77^{\prime}$ & $10.80 \mathrm{C} * * *$ & 6.585 & 3.627 \\
\hline dum_f1 $\times$ fuel 1 & & & & 0.403 & & 0.396 \\
\hline $\mathrm{i}$ & & & & & $2.099 *$ & 0.616 \\
\hline $\mathrm{c}$ & & $-1.806 *$ & & -2.144 & & -0.363 \\
\hline
\end{tabular}

\footnotetext{
${ }^{3}$ We have performed the same analysis for a third sample, represented by the old EU members (EU-12). The results do not significantly differ from those reported in the paper and can be provided by the authors upon request.

${ }^{4}$ The GMM findings for the robustness analysis are presented in Tables A1 and A2 (Appendix) and show results in agreement with those reported for the EU-28 panel.
}

DOI: 10.24818/18423264/54.1.20.02 
Eugenia Grecu, ClaudiuTiberiuAlbulescu, Ion Profir Pârțachi, StelianStancu, Daniela Traşcă

Notes: $(i) * * *, * *, *$ indicates significance at 1\%, 5\% and 10\%; (ii) $i$-inflation rate, iuinflation uncertainty, yu - output uncertainty, fuell - gasoline retail prices; dum_fl $\times$ fuell - interaction dummy between fuell and dum_fl (which takes value 1 if the gasoline price increases in t compared to $t-1$ and 0 otherwise), $c$-intercept, $\phi_{i}$-adjustment coefficient.

Second, when we look to the results reported for the diesel prices (Table 7), we observe that they are largely in agreement with those reported in Table 5, showing thus that there is no sample bias. As in the previous case, the gasoline prices exercise a slightly short-run stronger influence on the output compared with the diesel prices.

Table 7. MG robustness results (diesel prices)

\begin{tabular}{|c|c|c|c|c|c|c|}
\hline \multirow{2}{*}{$\begin{array}{l}25 \text { cross- } \\
\text { sections }\end{array}$} & \multicolumn{2}{|c|}{ Model 1} & \multicolumn{2}{|c|}{ Model 2} & \multicolumn{2}{|c|}{ Model 3} \\
\hline & $\begin{array}{l}\text { Long-run } \\
\text { coefficient }\end{array}$ & $\begin{array}{l}\text { Short-run } \\
\text { coefficient }\end{array}$ & $\begin{array}{l}\text { Long-run } \\
\text { coefficients }\end{array}$ & $\begin{array}{l}\text { Short-run } \\
\text { coefficients }\end{array}$ & $\begin{array}{l}\text { Long-run } \\
\text { coefficients }\end{array}$ & $\begin{array}{l}\text { Short-run } \\
\text { coefficients }\end{array}$ \\
\hline$\phi_{i}$ & & $-0.588 * * *$ & & $-0.507 \quad * * *$ & & $-0.318 * *$ \\
\hline iu & $-2.26 £ * * *$ & $0.515 * * *$ & -2.197 * & 0.345 & -6.6 & -0.400 \\
\hline yu & $2.379 * * *$ & -0.011 & $2.791 * * *$ & 0.104 & 6.6 & 0.343 \\
\hline fuel2 & $11.61 ; * *$ & $10.362 * * *$ & 12.601 & $9.901 * * *$ & 70.407 & 3.353 \\
\hline $\mathrm{dum}_{12} \mathrm{f} 2 \times \mathrm{fu}$ & & & & 0.170 & & 0.006 \\
\hline i & & & & & -1.100 & $1.554 *$ \\
\hline 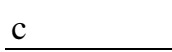 & & -0.605 & & -1.363 & & -4.624 \\
\hline \multicolumn{7}{|c|}{$\begin{array}{l}\text { Notes: }(i) * * *, * *, * \text { indicates significance at } 1 \%, 5 \% \text { and } 10 \% ;(\text { ii) } i \text {-inflation rate, iu- } \\
\text { inflation uncertainty, yu - output uncertainty, fuel } 2-\text { diesel retail prices; dum_fl } \times \text { fuell - } \\
\text { interaction dummy between fuel } 2 \text { and dum_f2 (which takes value } 1 \text { if the diesel price }\end{array}$} \\
\hline
\end{tabular}

\section{Conclusions}

Resorting to a panel data analysis for EU-28 countries over the period 2005 to 2017, we have tested the Friedman's (1977) second hypothesis, considering not only the influence of inflation uncertainty on economic output, but also the role of output uncertainty and fuel prices. We have tested different model specifications and we have used different estimators, namely a GMM and MG approach.

Our GMM results confirmed by both a difference- and a system-GMM model, show that the inflation uncertainty positively impacts the economic output in the EU countries. It is well-known that the EU economies experienced a low level of inflation in the aftermath of the recent global crisis. In this context, the risk of deflation impended the economic growth reprisal and any expansionary policy generated inflation uncertainty, with a favorable impact on the economic output. This results contrast to most of previous finings reported in the literature but is further sustained by our MG analysis. In fact, at the EU level it seems that the inflation uncertainty has a positive impact on the output only in the short run, whereas in the long run, the impact becomes negative.

DOI: $10.24818 / 18423264 / 54.1 .20 .02$ 
Output, Uncertainty and Fuel Prices in the EU Countries

We have also shown that the influence of the fuel prices on the economic output are positive and significant in the short run, but also in the long run (when the diesel prices are considered). This result has political implications and does not sustain the social movements recorded in some EU countries related to the protest against the increase in fuel prices. Although the level of fuel prices in the EU is very high given the excise taxes and carbon taxes applied by different governments, those prices are mainly driven by the consumption level and their impact on the economic output seems to be positive. Our results are robust to different specifications and samples.

To sum up our findings, we have validated the Friedman's (1977) second hypothesis in the long but not in the short run, we have obtained mixed results regarding the impact of output uncertainty on the economic growth, and we have reported a positive influence of fuel prices on the economic output. In addition, the fuel price levels and not their increases have a positive impact on the economic growth.

\section{ACKNOWLEDGMENTS}

For author Eugenia GRECU: This research was partially supported by Horizon2020-2017-RISE-777911 project.

For author ClaudiuTiberiu ALBULESCU: This work was supported by a grant of the Romanian National Authority for Scientific Research and Innovation, CNCS-UEFISCDI, project number PN-III-P1-1.1-TE-2016-0142.

\section{REFERENCES}

[1] Albulescu, C.T., Tiwari, A.K., Miller, S.M., Gupta, R.( 2019),Timefrequency Relationship between US Inflation and InflationUncertainty:Evidence from Historical Data. Scottish Journal of Political Economy, 66: 673-702;

[2] Arellano, M., Bond, S.R. (1991),Some Tests of Specification for Panel Data: Monte Carlo Evidence and an Application to Employment Equations. Review of Economic Studies, 58: 277-297;

[3] Balaji, B.,Durai, S.R.S., Ramachandran M.(2017),The Relationship between Output Uncertainty and Economic Growth-Evidence from India. Economics Bulletin, 37:2680-2691;

[4] Ball, L. (1992), Why Does High Inflation Raise Inflation Uncertainty?. Journal of Monetary Economics, 29:371-388;

[5]Bhar, R., Mallik, G.(2013), Inflation Uncertainty, Growth Uncertainty, Oil Prices, and Output Growth in the UK. Empirical Economics, 45:1333-1350; [6]Black, F.(1987),Business Cycles and Equilibrium, New York, Basil Blackwell, 167-190;

[7]Blundell, R.W., Bond, S.R. (1998), Initial Conditions and Moment

Restrictions in Dynamic Panel Data Models. Journal of Econometrics, 87: 115-143;

DOI: 10.24818/18423264/54.1.20.02 
Eugenia Grecu, ClaudiuTiberiuAlbulescu, Ion Profir Pârțachi, StelianStancu, Daniela Trașcă

[8] Chan, J.C.C.( 2017),The Stochastic Volatility in Mean Model with TimeVarying Parameters: An Application to Inflation Modeling. Journal of Business \& Economic Statistics, 35:17-28;

[9]Cukierman, A., Meltzer, A. (1986), A Theory of Ambiguity, Credibility, and Inflation under Discretion and Asymmetric Information. Econometrica, 54: 1099-1128;

[10]Ekrem, Y., Sancar, C. (2019),The Effect of Interest Rate on Output Level and Inflation in Turkey: Evaluation of Monetarist and New Keynesian Perspective. Economic Computation and Economic Cybernetics Studies and Research; ASE Publishing, 53(3): 257-275;

[11]Friedman, M.(1968), The Role of Monetary Policy. American Economic Review, 58: 1-17;

[12]Friedman, M. (1977),Nobel Lecture: Inflation and Unemployment. Journal Of Political Economy, 85: 451-472;

[13]Jiranyakul, K., Opiela, T.P.(2011),The Impact of Inflation Uncertainty on Output Growth and Inflation in Thailand. Asian Economic Journal, 25:291-307; [14]Karanfil, F., Yeddir-Tamsamani, Y. (2010), Is Technological Change Biased toward Energy? A Multi-Sectoral Analysis for the French Economy. Energy Policy, 38:1842-1850;

[15]López-Villavicencio A., Pourroy M. (2019),Inflation Target and (A)Symmetries in the Oil Price Pass-Through to Inflation. Energy Economics, 80: 860-875;

[16]Mo, B., Chen, C., Nie, H., Jiang, Y. (2019),Visiting Effects of Crude Oil Price on Economic Growth in BRICS Countries: Fresh Evidence from Waveletbased Quantile-on-Quantile Tests. Energy, 178: 234-251;

[17]Mohd, S.H.,Baharumshah, A.Z., Fountas, S. (2013),Inflation, Inflation Uncertainty and Output Growth: Recent Evidence from Asean-5 Countries. The Singapore Economic Review, 58: 1-17;

[18]Narayan, P.K., Sharma, S., Poon, W.C., Westerlund, J. (2014),Do Oil Prices Predict Economic Growth? New global evidence. Energy Economics, 41:137-146;

[19]Ö̈zdemir, Z.A.(2010),Dynamics of Inflation, Output Growth and their Uncertainty in the UK: An Empirical Analysis. The Manchester School, 78: 511-537;

[20]Pesaran M.H., Shin Y., Smith, R.P. (1997),Pooled Mean Group Estimation of Dynamic Heterogeneous Panels. Journal of the American Statistical Association, 94:621-634;

[21]Pesaran M.H., Smith, R.P. (1995),Estimating Long-run Relationships from Dynamic Heterogeneous Panels. Journal of Econometrics, 68: 79-113;

[22]Pintilescu, C, Jemna, D.V., Viorică, E.D., Asandului, M. (2014),Inflation, Output Growth, and their Uncertainties: Empirical Evidence for a Causal Relationship from European Emerging Economies. Emerging Markets Finance \& Trade, 50:78-94; 
Output, Uncertainty and Fuel Prices in the EU Countries

[23]Ungar, M., Zilberfarb, B-Z. (1993),Inflation and its Unpredictability-theory and Empirical Evidence. Journal of Money, Credit and Banking, 25:709-720; [24]van Eyden, R., Difeto, M., Gupta, R., Wohar, M.E.( 2019), Oil price volatility and economic growth: Evidence from Advanced Economies Using more than a Century's dat. Applied Energy, 233-234:612-621;

[25]Zha, D., Kavuri, A.S., Si, S.(2018),Energy-biased Technical Change in the Chinese Industrial Sector with CES Production Functions. Energy, 148: 896903.

\section{Appendix}

Table A1. GMM robustness results (gasoline prices)

\begin{tabular}{|c|c|c|c|c|c|c|}
\hline \multirow{2}{*}{$\begin{array}{l}25 \text { cross- } \\
\text { sections }\end{array}$} & \multicolumn{3}{|c|}{ difference-GMM } & \multicolumn{3}{|c|}{ system-GMM } \\
\hline & Model 1 & Model 2 & Model 3 & Model 1 & Model 2 & Model 3 \\
\hline $\operatorname{lag}(1)$ & $0.469 * * *$ & $0.476 * * *$ & $0.446 * * *$ & $0.489 * * *$ & $0.489 * * *$ & $0.441 * * *$ \\
\hline iu & $0.240 * * *$ & 0.140 & -0.130 & $0.235^{* * *}$ & $0.235 * * *$ & $-0.467 * *$ \\
\hline $\mathrm{yu}$ & $1.188 * * *$ & $1.181 * * *$ & $1.175 * * *$ & $1.278 * * *$ & $1.278 * * *$ & $1.279 * * *$ \\
\hline fuel1 & $8.501 * * *$ & $7.753 * * *$ & $7.231 * * *$ & $9.258 * * *$ & $9.258 * * *$ & $7.271 * * *$ \\
\hline dum $\mathrm{f} 1 \times$ fuel 1 & & 0.781 & $0.886^{*}$ & & & $1.066 * *$ \\
\hline $\mathrm{i}$ & & & 0.216 & & & $0.509 * * *$ \\
\hline \multirow[t]{2}{*}{$\mathrm{c}$} & - & - & - & - & - & - \\
\hline & $3.826 * * *$ & $3.627 * * *$ & $3.703 * * *$ & $4.271 * * *$ & $4.271 * * *$ & $4.284 * * *$ \\
\hline observations & 275 & 275 & 275 & 300 & 300 & 300 \\
\hline instruments & 136 & 137 & 189 & 158 & 158 & 222 \\
\hline
\end{tabular}

Notes: ( $i)$ lag( 1 ) is the first lag of the dependent variable; (ii) dummy variables are considered strictly exogenous; (iii) *,**,*** means significance at $10 \%, 5 \%$ and $1 \%$; (iv) $i$-inflation rate, iu - inflation uncertainty, yu-output uncertainty, fuell - gasoline retail prices; dum_fl $\times f u e l 1$ - interaction dummy between fuell and dum_fl (which takes value 1 if the gasoline price increases in tcompared to $t-1$ and 0 otherwise), $c$-intercept.

DOI: 10.24818/18423264/54.1.20.02 
Eugenia Grecu, ClaudiuTiberiuAlbulescu, Ion Profir Pârțachi, StelianStancu, Daniela Trașcă

Table A2. GMM robustness results (diesel prices)

\begin{tabular}{|c|c|c|c|c|c|c|}
\hline \multirow{2}{*}{$\begin{array}{l}25 \text { cross- } \\
\text { sections }\end{array}$} & \multicolumn{3}{|c|}{ difference-GMM } & \multicolumn{3}{|c|}{ system-GMM } \\
\hline & Model 1 & Model 2 & Model 3 & Model 1 & Model 2 & Model 3 \\
\hline $\operatorname{lag}(1)$ & $0.455 * * *$ & $0.463 * * *$ & $0.435 * * *$ & $0.475 * * *$ & $0.490 * * *$ & $0.430 * * *$ \\
\hline iu & $0.190 * *$ & 0.090 & -0.160 & $0.161 * *$ & -0.020 & $\overline{-}-511 * * *$ \\
\hline yu & $1.195 * * *$ & $1.189 * * *$ & $1.186^{* * *}$ & $1.290 * * *$ & $1.282 * * *$ & $1.286 * * *$ \\
\hline fuel2 & $7.170 * * *$ & $6.468 * * *$ & $6.027 * * *$ & $8.193 * * *$ & $7.202 * * *$ & $6.279 * * *$ \\
\hline dum_f $2 \times$ fuel 2 & & 0.740 & $0.847 *$ & & $1.083 * * *$ & $1.035 * * *$ \\
\hline $\mathrm{i}$ & & & 0.203 & & & $0.495 * * *$ \\
\hline $\mathrm{c}$ & - & - & - & - & - & - \\
\hline & $3.325 * * *$ & $3.131 * * *$ & $3.218 * * *$ & $3.955 * * *$ & $3.695 * * *$ & $3.930 * * *$ \\
\hline observations & 275 & 275 & 275 & 300 & 300 & 300 \\
\hline instruments & 136 & 137 & 189 & 159 & 159 & 222 \\
\hline
\end{tabular}

Notes: (i) lag(1) is the first lag of the dependent variable; (ii) dummy variables are considered strictly exogenous; (iii) *,**, *** means significance at $10 \%, 5 \%$ and $1 \%$; (iv) $i$-inflation rate, iu - inflation uncertainty, yu-output uncertainty, fuel2 - diesel retail prices; dum_f $2 \times f u e l 2$ - interaction dummy between fuel 2 and dum_ $f 2$ (which takes value 1 if the diesel price increases in t compared to $t-1$ and 0 otherwise), $c$-intercept. 